\title{
Comprehensive or Political Liberalism? The Impartial Spectator and the Justification of Political Principles
}

\author{
Nir Ben-Moshe \\ University of Illinois at Urbana-Champaign \\ E-mail: nir@illinois.edu
}

\begin{abstract}
John Rawls raises three challenges - to which one can add a fourth challenge - to an impartial spectator account: (a) the impartial spectator is a utility-maximizing device that does not take seriously the distinction between persons; (b) the account does not guarantee that the principles of justice will be derived from it; (c) the notion of impartiality in the account is the wrong one, since it does not define impartiality from the standpoint of the litigants themselves; (d) the account would offer a comprehensive, rather than a political, form of liberalism. The narrow aim of the article is to demonstrate that Adam Smith's impartial spectator account can rise to Rawls's challenges. The broader aim is to demonstrate that the impartial spectator account offers the basis for a novel and alternative framework for developing principles of justice, and does so in the context of a political form of liberalism.
\end{abstract}

\section{Introduction}

In his A Theory of Justice, John Rawls raises three challenges - to which one can add a fourth challenge on Rawls's behalf - to an impartial spectator framework, thereby rendering it an inviable alternative to his own contractarian framework for developing principles of justice. ${ }^{1}$ First, Rawls raises a "utilitarian challenge": ${ }^{2}$ since, according to a utilitarian view of justice, it does not matter how the sum of satisfactions is distributed among individuals - as long as the correct distribution yields maximum fulfillment - one could "adopt for society as a whole the principle of rational choice for one man"; this task is performed, according to Rawls, by the impartial spectator, who organizes "the desires of all persons into one coherent system of desire." So insofar as the impartial spectator is a utility-maximizing device, this spectator fuses all of the relevant persons into one

\footnotetext{
${ }^{1}$ While Smith is not always the clear or sole target of Rawls's attack - at times Rawls lumps Smith together with Hume, Sidgwick, and Firth when discussing "impartial spectator" accounts - any framework that wishes to make use of ideal observer reasoning to justify political principles will need to respond to Rawls's criticisms. Of course, the idealization in Smith's impartial spectator account is substantially more modest than the one in Firth's account.

${ }^{2}$ The names of the four challenges are my addition; Rawls does not give these challenges titles.

(c) The Author(s), 2021. Published by Cambridge University Press. This is an Open Access article, distributed under the terms of the Creative Commons Attribution licence (http://creativecommons.org/licenses/by/4.0/), which permits unrestricted re-use, distribution, and reproduction in any medium, provided the original work is properly cited.
} 
person and "does not take seriously the distinction between persons" (TJ 24). ${ }^{3}$ Second, and relatedly, Rawls raises a "wrong type of impartiality challenge": the notion of impartiality in the impartial spectator account is the wrong one, since, unlike Rawls's original position account, it does not "define impartiality from the standpoint of the litigants themselves" (TJ 165), but rather from the standpoint of the impartial spectator. Rawls sees this objection as tied to utilitarianism's aggregation and thus concludes that an impartial spectator account, like any utilitarian account, "mistakes impersonality for impartiality" (TJ 166). Third, Rawls raises an "insufficient content challenge": there is nothing about an impartial spectator that guarantees that the principles of justice will be derived from it. In particular, while Rawls's contractarianism aims to provide a "deductive basis" for the principles of right and justice via the original position and the motivation of the parties, "the impartial spectator definition makes no [psychological] assumptions from which the principles of right and justice may be derived" (TJ 161-62). Fourth, one can add a "wrong type of liberalism challenge" on Rawls's behalf: since, according to Rawls's understanding of the impartial spectator, political principles are justified by appealing to a larger framework of values - maximizing utility (in the form of desire satisfaction) - the emerging account is one of comprehensive, rather than political, liberalism. ${ }^{4}$

I have both a narrow and a broad aim in this article. The narrow aim is to demonstrate that Adam Smith's impartial spectator account in The Theory of Moral Sentiments can rise to Rawls's challenges. The broad aim is to demonstrate that the impartial spectator account, in conjunction with some of Smith's other views, offers the basis for a novel and alternative framework for developing principles of justice, and does so in the context of a political, rather than a comprehensive, form of liberalism. In particular, rather than appealing to the decisions of mutually disinterested individuals concerned to further their own interests under a veil of ignorance, ${ }^{5}$ the Smithian account appeals to the decisions of other-regarding, sympathetic individuals under conditions of full knowledge and impartiality. As I will argue, this type of sentimentalist alternative can ultimately yield Rawlsian results. I proceed as follows. After presenting Smith's account of the impartial spectator as well as key methodological points (section 2), I draw analogies between the Rawlsian and Smithian projects (section 3) and explain which principles of justice are likely to be developed from the impartial spectator framework (section 4). I then respond to Rawls's challenges to an impartial spectator account (section 5) and conclude by explaining why the account is one of political, rather than comprehensive, liberalism (section 6). I should note, before proceeding, that I will not be fully fleshing out the Smithian framework in the current article. Rather, my "broad aim" is limited to showing that there is space to develop an interesting Smithian version of political liberalism and to gesture at the principles of justice that are likely to be derived from this framework, principles that are Rawlsian in nature.

\section{The impartial spectator and justice: preliminary remarks}

Smith's account of the impartial spectator, which is a standpoint from which we judge ourselves as well as others, is, in the first instance, an account of moral judgment. Smith

\footnotetext{
3“TJ" refers to John Rawls, A Theory of Justice, rev. edn (Cambridge, MA: Harvard University Press, 1999).

${ }^{4}$ For Rawls's discussion of the difference between comprehensive and political liberalism, see PL 195200. "PL" refers to John Rawls, Political Liberalism, expanded edn (New York: Columbia University Press, 2005).

${ }^{5}$ Rawls takes "disinterestedness" to mean "not taking an interest in one another's interests" or "not willing to have [one's] interests sacrificed to the [sic] others" (TJ 12 \& 112).
} 
observed that it is part and parcel of human life that we judge others and find others judging us. This allows us to see ourselves through the eyes of others, by internalizing the way in which others respond to us, and thus to make judgments of the propriety of our own sentiments (TMS III.1.3-5). ${ }^{6}$ However, Smith was also sensitive to the fact that agents in a society might come to realize that the actual spectators who judge them are biased, either because they are not informed about the relevant facts or because they have a personal stake in the circumstances, and are thus unreliable sources for determining what is worthy of approval (TMS III.2.4-5). This realization is a product of our desire to be worthy of approval: we are the type of creature that does not merely desire praise and dread blame, but that comes to desire being praise-worthy and dread being blame-worthy (TMS III.2.1). Hence, Smith argues that agents will seek to go beyond the actual bystanders they encounter and use their imagination to create an impartial spectator: "We endeavour to examine our own conduct as we imagine any other fair and impartial spectator would examine it" (TMS III.1.2). More specifically, the impartial spectator is "gradually formed from [our] observations upon the character and conduct both of [ourselves] and of other people" (TMS VI.iii.25): we use our imagination to build on our interactions with others and construct an image of a wellinformed and impartial bystander. While this account, as presented thus far, is one of what is appropriate (TMS VII.ii.1.49), and not of what is fair, Smith also makes use of the impartial spectator to provide an account of "commutative justice" (TMS VII.ii.1.10). In particular, he writes of injustice that it is an "injury," which "does real and positive hurt to some particular persons, from motives which are naturally disapproved of" and so is "the proper object of resentment, and of punishment, which is the natural consequence of resentment" (TMS II.ii.1.5). In other words, injustice is defined not only by the fact that it is the result of inappropriate motives, but also by injury that causes spectators to feel resentment, which is "the safeguard of justice" (TMS II.ii.1.4-5). ${ }^{7}$ And as is the case with sentiments quite generally, our sentiments of resentment are warranted or "proper" only "when the heart of every impartial spectator entirely sympathizes with them, when every indifferent bystander entirely enters into, and goes along with, them" (TMS II.i.2.2). Therefore, judgments of injustice are correct, on Smith's account, when we experience resentment at some injury from a fully informed and impartial standpoint.

Smith's account of commutative justice does not yet get us the type of principles of justice that are required for his claim that "the first and chief design of every system of government is to maintain justice" (LJ (A) i.1). ${ }^{8}$ In order to attain this end, we need an account of distributive justice. But let me commence with three methodological points. First, when Smith himself refers to "distributive justice," he is using the term in its premodern, rather than modern, sense:

[W] e are said not to do justice to our neighbour unless we conceive for him all that love, respect, and esteem, which his character, his situation, and his connection

\footnotetext{
6"TMS" refers to Adam Smith, The Theory of Moral Sentiments, ed. by D. D. Raphael and A. L. Macfie (Indianapolis: Liberty Fund, 1976).

${ }^{7}$ For further discussion of the role of resentment in Smith's account of justice, see Stephen Darwall, Sympathetic Liberalism: Recent Work on Adam Smith, Philosophy \& Public Affairs, 2 (1999): 139-64, at pp. 142-43 and Charles L. Griswold, Adam Smith and the Virtues of Enlightenment (New York: Cambridge University Press, 1999), p. 239.

8"L" refers to Adam Smith, Lectures on Jurisprudence, ed. by R. L. Meek, D. D. Raphael, and P. G. Stein (Indianapolis: Liberty Fund, 1978). The "(A)" refers to Smith's Jurisprudence lectures in the 1762-63 session.
} 
with ourselves, render suitable and proper for us to feel, and unless we act accordingly. [...] [This] sense of the word coincides with what some have called distributive justice, [. . .] which consists in proper beneficence, in the becoming use of what is our own, and in the applying it to those purposes, either of charity or generosity, to which it is most suitable in our situation that it should be applied. In this sense justice comprehends all the social virtues. [TMS VII.ii.1.10]

The notion of distributive justice that Smith inherited is one in which this form of justice is: (a) a private virtue, not a task for the state or the government; (b) connected to all the social virtues - it includes, for example, duties of parents to children and of friends and neighbors to one another - and is not primarily directed at relieving the misery of the poor; (c) associated with matching goods to merit, rather than need, and has little to do with property arrangements. ${ }^{9}$ Nevertheless, I will incorporate some of Smith's general observations - about the poor in particular - into his impartial spectator account in order to propose a Smithian framework for developing principles of distributive justice in the modern sense. Second, insofar as Smith's impartial spectator account can be used to develop a liberal political conception of justice, the principles of justice inherent in the account can deviate from Rawls's two principles of justice. Indeed, Rawls himself conceded in Political Liberalism that while he views "justice as fairness" and its two principles of justice as the most reasonable conception, he cannot deny that other conceptions might also satisfy the definition of a liberal political conception of justice (PL xlvi-ii). Nevertheless, I will demonstrate that there are good reasons to hypothesize that the principles of justice derived from the proposed Smithian framework will include a principle of equality of basic liberties for all, coupled with either (a) a principle of equality in the distribution of social status and material goods, or (b) a principle that maintains that social and economic inequalities are just only if the least advantaged members of society are not unreasonably disadvantaged.

The third methodological point requires lengthier discussion. The impartial spectator is very attuned to the specifics of the situation. Nevertheless, Smith believed in the existence of "rules of justice," which he compares to "the rules of grammar" in the sense that they are "accurate in the highest degree, and admit of no exceptions or modifications but such as may be ascertained as accurately as the rules themselves" (TMS III.6.10-11). So how can we formulate general rules and principles using the standpoint of the impartial spectator? First, Smith puts a lot of emphasis on the imagination and counterfactual reasoning in TMS, which allow us to free ourselves from the responses of actual people. For example, by imagining being in the victim's situation, we frequently experience resentment against injustice even when those suffering the injustice do not (TMS II.i.2.5). ${ }^{10}$ Second, we come to formulate general rules and principles given the strong reactions that we have towards certain actions, especially when others have similar reactions:

Some of [other people's] actions shock all our natural sentiments. We hear every body about us express the like detestation against them. This still further confirms,

\footnotetext{
${ }^{9}$ These observations are taken from Samuel Fleischacker, A Short History of Distributive Justice (Cambridge, MA: Harvard University Press, 2004), pp. 17-19 and 27. See also LJ (A) i.14-15.

${ }^{10}$ For an excellent discussion of counterfactual reasoning in Smith's account of sympathy, see Eric Schliesser, Adam Smith: Systematic Philosopher and Public Thinker (New York: Oxford University Press, 2017), pp. 118-21.
} 
and even exasperates, our natural sense of their deformity. It satisfies us that we view them in the proper light, when we see other people view them in the same light. [. . .] We thus naturally lay down to ourselves a general rule, that all such actions are to be avoided [...]. Other actions, on the contrary, call forth our approbation, and we hear every body around us express the same favourable opinion concerning them. [...] They excite all those sentiments for which we have by nature the strongest desire [. . .]. We [. . .] naturally lay down to ourselves a rule of another kind, that every opportunity of acting in this manner is carefully to be sought after. (TMS III.4.7)

Moreover, we can formulate general rules and principles by induction, that is, by surveying cases and inferring the badness or goodness of a feature of those cases from that survey. Thus, Smith argues that "the general rules of morality" are "ultimately founded upon experience of what, in particular instances, our moral faculties, our natural sense of merit and propriety, approve or disapprove of," that is, "by finding from experience that all actions of a certain kind, or circumstanced in a certain manner, are approved or disapproved of" (TMS III.4.8). Note that in both quotes the generalization in question is not one made from our sentiments as they are, but rather from our sentiments as experienced from the standpoint of the impartial spectator: this is suggested in Smith's talk of seeing the sentiments "in the proper light" and his talk of "natural sense" and the desires we have "by nature," which he often uses to refer to sentiments felt from the standpoint of the impartial spectator. Accordingly, if we build on these suggestions, the principles of justice can be derived by agreement among those agents who adopt the standpoint of the impartial spectator. More specifically, those adopting the standpoint of the impartial spectator can share their verdicts, and/or their verdicts can be compared to each other by others, in order to formulate these principles. When general rules have been established, "we frequently appeal to them as to the standards of judgment, in debating concerning the degree of praise or blame that is due to certain actions"; they correct "the misrepresentations of self-love concerning what is fit and proper to be done" and are "commonly cited as the ultimate foundations of what is just and unjust in human conduct" (TMS III.4.11-12). Therefore, generalizations based on the more specific judgments of the impartial spectator can, in fact, form the "rules of justice."

\section{Rawls and Smith: analogies}

Rawls's "veil of ignorance" is supposed to provide the conditions under which parties can reach agreement about the principles of justice, "principles that free and rational persons concerned to further their own interests would accept in an initial position of equality as defining the fundamental terms of their association" (TJ 10). The idea of developing principles of justice under conditions of equality is one that Smith would most likely endorse, for he makes claims that are friendly to the idea of equality between human beings. Thus, he argues that "the difference between the most dissimilar characters, between a philosopher and a common street porter, for example, seems to arise not so much from nature, as from habit, custom, and education" (WN I.ii.4; ${ }^{11}$ see also $\mathrm{LJ}(\mathrm{A})$ vi.47-48). He also notes that the concern associated with redress towards

11"WN" refers to Adam Smith, An Inquiry into the Nature and Causes of the Wealth of Nations, ed. by R. H. Campbell and A. S. Skinner (Indianapolis: Liberty Fund, 1976). 
injured parties is "the general fellow-feeling which we have with every man, merely because he is our fellow-creature" (TMS II.ii.3.10). Relatedly, Smith was keenly aware of the importance of respecting the dignity of human beings. He writes, for example, that what "resentment is chiefly intent upon, is not so much to make our enemy feel pain in his turn, as [. . . ] to make him sensible, that the person whom he injured did not deserve to be treated in that manner" and that "what chiefly enrages us against the man who injures or insults us, is the little account which he seems to make of $u s^{\text {" }}$ (TMS II.iii.1.5; emphasis added). Smith thus believed that we resent injuries to our dignity, that is, to our status as persons who may not be treated in certain ways. ${ }^{12}$ Furthermore, and most importantly, when a spectator adopts the standpoint of the impartial spectator, he "sees that to [others] he is but one of the multitude in no respect better than any other in it," which humbles his self-love (TMS II.ii.2.1, III.3.4, \& VI.ii.2.2). ${ }^{13}$ Moreover, this standpoint allows the spectator to correct his perception of his own interests (which are tied to his self-love) versus the interests of others. The key idea is simple: if we want to weigh the importance of our interests versus the importance of someone else's interests, "[w]e must view them, neither from our own place nor yet from his, neither with our own eyes nor yet with his, but from the place and with the eyes of a third person, who has no particular connexion with either, and who judges with impartiality between us" (TMS III.3.3). Therefore, adopting the standpoint of the impartial spectator makes us appreciate that our own interests and points of view are no more privileged than - indeed, are equal to - other people's interests and points of view.

One can draw further analogies between Rawls's understanding of equality under the veil of ignorance and key components of Smith's moral philosophy. In particular, Rawls argues that equality under those conditions is equality between human beings as "moral persons," that is, as creatures who, among other things, (a) regard themselves as self-authenticating sources of valid claims, and (b) are capable of a sense of justice understood as an effective desire to act upon the principles of justice (TJ $17 \& 442$ and PL 29-34). ${ }^{14}$ Smith develops an account of what he calls a "moral being" in terms of accountability: "Man is considered as a moral [being], because he is regarded as an accountable being"; more specifically, "A moral being is an accountable being. An accountable being, as the word expresses, is a being that must give an account of its actions to some other, and that consequently must regulate them according to the goodliking of this other. Man is accountable to God and his fellow creatures."15

\footnotetext{
${ }^{12}$ This point is taken from Darwall, Sympathetic Liberalism: Recent Work on Adam Smith, pp. 144-45 and Stephen Darwall, Equal Dignity in Adam Smith, in The Adam Smith Review, vol. 1, ed. by Vivienne Brown (London \& New York: Routledge, 2004), pp. 129-34, at pp. 132-33.

${ }^{13}$ Smith believed that self-love makes it difficult for us to see things from other people's perspectives (TMS III.4.3). The impartial spectator humbles our self-love, as do the generalizations based on the judgments of this spectator (see section 2).

${ }^{14}$ Rawls also argues that moral persons have a conception of their good as expressed by a rational plan of life. While I will not draw analogies between Rawls and Smith on this point, there is no reason to suppose that Smith would be opposed to understanding moral persons under conditions of equality as including this third characteristic. Indeed, Smith's talk of weighing different people's interests from the standpoint of the impartial spectator would seem amenable to the idea that the people in question each have a conception of their own good.

${ }^{15}$ The longer quote is taken from a passage that appeared in editions $1-5$ of TMS, but was withdrawn in the sixth edition. The shorter quote was added in editions $2-5$. See footnote on p. 111 of the Glasgow Edition (1976) of TMS.
} 
Accountability, understood as giving an account of our actions to our fellow moral beings, means that we can make claims on each other and be sources of claims. Of course, the claims in question will be valid only if we understand accountability in normative terms. In particular, those holding others accountable need to be justified in doing so, which would be the cases if and only if the claims in question are made from the standpoint of the impartial spectator. This is so because those agents who adopt this standpoint know what constitutes the morally appropriate and inappropriate when making claims on others and thus have the right kind of authority. ${ }^{16}$ Hence, one can understand agents who adopt the standpoint of the impartial spectator as regarding themselves and others as self-authenticating sources of valid claims. Moreover, while Rawls argues that moral agents have an effective desire to act upon the principles of justice, Smith postulates, as noted, that we are the type of creature that desires to be worthy of approval: praiseworthiness and blameworthiness express what "ought to be the sentiments of other people with regard to our character and conduct" and the love of praiseworthiness is "the desire of rendering ourselves the proper objects of those sentiments" (TMS III.2.25). It is only the impartial spectator, whose jurisdiction is founded "in the desire of praise-worthiness, and in the aversion to blame-worthiness" (TMS III.2.32), who can reliably praise us for doing what is worthy of approval and so satisfy this desire. Indeed, the desire to be worthy of approval can be satisfied if we know that the impartial spectator would approve of our actions, even if such approval is not provided by those around us (TMS III.2.5). So people will tend to be motivated to adopt the standpoint of the impartial spectator and act on principles of justice, insofar as those principles are developed from this standpoint.

\section{The impartial spectator and the principles of justice}

In terms of developing principles of justice, Smith certainly wanted an equal assignment of basic rights and liberties, as suggested by his remark in The Wealth of Nations that "to hurt in any degree the interest of any one order of citizens, for no other purpose but to promote that of some other, is evidently contrary to that justice and equality of treatment which the sovereign owes to all the different orders of his subjects" (WN IV.viii.30). And Smith's impartial spectator account is especially amenable to Rawls's first principle of justice, according to which "each person has the same indefeasible claim to a fully adequate scheme of equal basic liberties, which scheme is compatible with the same scheme of liberties for all" (JF 42). ${ }^{17}$ This is so because, as we saw, it is from the standpoint of the impartial spectator that we see that we are "one of the multitude" and "in no respect better than any other in it." In particular, any person who adopts the standpoint of the impartial spectator sees that her interests and perspective are equal to those of others, and thus she ought to be able to see that whatever basic liberties are given to her should also be given to everyone else. Thus, while Rawls argues that the parties in the original position would choose the first principle of justice because of their symmetry - in the sense of it not being reasonable for a given agent to expect more than an equal share in the division of social primary goods or rational

\footnotetext{
${ }^{16}$ I discuss this conceptualization of accountability in Nir Ben-Moshe, An Adam Smithian Account of Moral Reasons, European Journal of Philosophy (2019). Online First, <https://doi.org/10.1111/ejop.12495>.

${ }^{17}$ “JF" refers to John Rawls, Justice as Fairness: A Restatement, ed. by Erin Kelly (Cambridge, MA: The Belknap Press of Harvard University Press, 2001).
} 
for him to agree to less (TJ 130) - Smith can also appeal to the symmetry inherent in the standpoint of the impartial spectator: he can do so not in terms of what is most reasonable for promoting one's own interests, but in terms of the equality of interests and perspectives of the agents who adopt this standpoint. Furthermore, this line of reasoning, which builds on the equality of interests and perspectives, can be buttressed by Smith's account of commutative justice: given our experience with warranted sentiments of resentment - that is, sentiments of resentment experienced from the standpoint of the impartial spectator - towards injuries done to others, we can easily imagine the resentment we would feel from the injury incurred to someone who would not enjoy equal basic liberties. Smith himself uses an egalitarian line of reasoning in his discussion of the role of the impartial spectator in commutative justice:

In the race for wealth, and honours, and preferments, [an agent] may run as hard as he can [. . .] in order to outstrip all his competitors. But if he should justle, or throw down any of them, the indulgence of the [impartial] spectators is entirely at an end. It is a violation of fair play, which they cannot admit of. This man is to them, in every respect, as good as he: they do not enter into that self-love, by which he prefers himself so much to this other, and cannot go along with the motive from which he hurt him. They readily, therefore, sympathize with the natural resentment of the injured, and the offender becomes the object of their hatred and indignation. (TMS II.ii.2.1)

Is there also a case to be made that the impartial spectator account, perhaps in conjunction with Smith's other views, could accommodate Rawls's "difference principle," according to which "social and economic inequalities are to satisfy two conditions: first, they are to be attached to offices and positions open to all under conditions of fair equality of opportunity; and second, they are to be to the greatest benefit of the least-advantaged members of society" (JF 42-43)? When discussing the difference principle, Rawls notes that "society should take into account economic efficiency and the requirements of organization and technology" and asks "if there are inequalities in income and wealth, and differences in authority and degrees of responsibility, that work to make everyone better off in comparison with the benchmark of equality, why not permit them?" (TJ 130-31). Smith, for his part, was sympathetic to the idea that social arrangements should benefit the least advantaged members of society, not only because of considerations of efficiency, but, again and much like Rawls, also because of considerations of equality:

Is this improvement in the circumstances of the lower ranks of the people to be regarded as an advantage or as an inconveniency to the society? The answer seems at first sight abundantly plain. Servants, labourers and workmen of different kinds, make up the far greater part of every great political society. But what improves the circumstances of the greater part can never be regarded as an inconveniency to the whole. No society can surely be flourishing and happy, of which the far greater part of the members are poor and miserable. It is but equity, besides, that they who feed, cloath and lodge the whole body of the people, should have such a share of the produce of their own labour as to be themselves tolerably well fed, cloathed and lodged. (WN I.viii.36) 
There is also evidence that Smith was sensitive to the burdens of the poor, writing of "the poor labourer," for example, that he who "supports the whole frame of society and furnishes the means of the convenience and ease of all the rest is himself possessed of a very small share and is buried in obscurity." This laborer "bears on his shoulders the whole of mankind, and unable to sustain the load is buried by the weight of it and thrust down into the lowest parts of the earth, from whence he supports all the rest" (LJ (A) vi.28). Furthermore, in an early draft of WN, where Smith makes similar observations, he adds that if "the produce of the labour of the multitude was to be equally and fairly divided, each individual, we should expect, could be little better provided for than the single person who laboured alone," but also notes that "with regard to the produce of the labour of a great society there is never any such thing as a fair and equal division." 18 Therefore, Smith was skeptical of the possibility of equal division of goods in civilized societies. ${ }^{19}$

Nevertheless, given the equality of interests and perspectives from the standpoint of the impartial spectator, there clearly will be pressure towards equal distribution of social status and material goods when considering such matters from this standpoint. Hence, any deviation from such a distribution will need to be justified by an appeal to agents' situations and other pertinent considerations. Indeed, much like Rawls's claim that "taking equality as the basis of comparison, those who have gained more must do so on terms that are justifiable to those who have gained the least" (TJ 131), agents adopting the standpoint of the impartial spectator - who, as argued, also make valid claims on each other - will need to justify deviations from equal distribution to those who have gained the least. The difference principle is naturally a strong candidate for such justification, but it is not the only one. ${ }^{20}$ While I will not be demonstrating that the difference principle (or any other principle of distributive justice) can be deduced from the impartial spectator framework, there is much in this framework that makes it conducive to a principle that does not unreasonably disadvantage the least-advantaged members of society. In particular, Smith provides us with the resources required for imagining the lives of the poor. The hallmark of Smith's account of sympathy is that we imagine being in the situation we take the actor to be in (TMS I.i.1.2), so that sympathy "does not arise so much from the view of the passion, as from that of the situation which excites it" (TMS I.i.1.10). In part I of TMS, Smith argues that when we sympathize with A, we imagine how we would feel in A's situation (TMS I.i.1.10-13). However, in part VII of TMS, Smith argues that when we sympathize with A, we imagine how $A$ would feel in A's situation (TMS VII.iii.1.4). As I have argued elsewhere, the full development of the latter type of sympathy requires the attainment of the standpoint of the impartial spectator, and hence Smith discusses this type of sympathy towards the end of TMS, after he has presented his account of the impartial spectator. ${ }^{21}$ Thus, when the standpoint of the impartial spectator has been constructed, we can see the situation from another person's perspective. Therefore, insofar as we develop principles of justice

\footnotetext{
${ }^{18}$ Adam Smith, Early Draft of Part of The Wealth of Nations, in Lectures on Jurisprudence, ed. by R. L. Meek, D. D. Raphael, and P. G. Stein, (Indianapolis: Liberty Fund, 1978), pp. 562-81, at p. 563.

${ }^{19}$ For an excellent discussion of these points, as well as of Smith's views about the poor more generally, see Fleischacker, A Short History of Distributive Justice, pp. 62-68.

${ }^{20}$ One example of an alternative principle, which Rawls himself mentions, is "to improve social wellbeing subject to a constraint guaranteeing for everyone a sufficient level of adequate all-purpose means" (PL xlvii).

${ }^{21}$ Nir Ben-Moshe, Making Sense of Smith on Sympathy and Approbation: Other-Oriented Sympathy as a Psychological and Normative Achievement, British Journal for the History of Philosophy 28 (2020): 735-55.
} 
based on Smith's impartial spectator account, we will be doing so not only from our understanding of the situation of the least-advantaged members of society as it confronts us, but also from our understanding of their situation as it confronts them. And if we do not offer the poor equality in social status and material goods, we would have good reason to ensure that social and economic inequalities do not unreasonably disadvantage them. This is so not only because the poor make valid claims on us - although that is a reason too - but also because we understand their situation from their perspective and can do so from a standpoint that gives their perspective equal weight to our own.

\section{Responding to Rawls's challenges}

In The Wealth of Nations, Smith mentions "the establishment of perfect justice, of perfect liberty, and of perfect equality" (WN IV.ix.17). The impartial spectator can be used to establish principles of justice that do indeed allow for the greatest degree of equality that is compatible with the greatest degree of liberty: equal basic liberties, coupled with equal distribution of social and economic goods, or, alternatively, coupled with a principle that maintains that social and economic inequalities are just only if the least advantaged members of society are not unreasonably disadvantaged. Moreover, Smith's impartial spectator framework can retain the intuitions behind the Rawlsian ideals of "justice as fairness" and "the priority of the right over the good." In particular, whereas Rawls argued that "since all are similarly situated [behind the veil of ignorance] and no one is able to design principles to favor his particular condition, the principles of justice are the result of a fair agreement or bargain" (TJ 11), Smith's impartial spectator allows for the development of principles of justice under conditions of fairness in the sense that all perspectives and interests have equal status. And whereas Rawls argued that "the principles of justice set limits to permissible ways of life" and that "the claims that citizens make to pursue ends transgressing those limits have no weight" (PL 209), when agents determine principles of justice based on the standpoint of the impartial spectator, they are committing themselves to constraining their conceptions of the good by considerations of justice: the standpoint of the impartial spectator, from which one weighs competing interests from a neutral point of view that is not tainted by one's own interests, will impose restrictions on what are reasonable conceptions of one's good. These ideas are, of course, related to the question of whether the proposed impartial spectator account, when used for the development of principles of justice, is one of a comprehensive or political liberalism. I will return to that question in the next section, after first responding to Rawls's own challenges to an impartial spectator account.

In response to the "utilitarian challenge," Smith was not a utilitarian in his philosophical sensibilities, arguing that "the idea of the utility of all qualities of this kind [another man's judgment and taste] is plainly an afterthought, and not what first recommends them to our approbation" (TMS I.i.4.4). He also rejected utilitarianism as a general moral theory, writing in $\mathrm{WN}$ that sacrificing "the ordinary laws of justice to an idea of public utility [.. . ] can be pardoned only in cases of the most urgent necessity" (WN IV.v.b.39). And more to the point, the impartial spectator framework is not supposed to be one in which the spectator is a utility-maximizing device. As Smith notes, the impartial spectator would not approve of the following actions, which would be warranted from a utilitarian perspective: "One individual must never prefer himself so much even to any other individual as to hurt or injure that other in order 
to benefit himself, though the benefit to the one should be much greater than the hurt or injury to the other"; for example, "the poor man must neither defraud nor steal from the rich, though the acquisition might be much more beneficial to the one than the loss could be hurtful to the other" (TMS III.3.6). In terms of the "wrong type of impartiality challenge," by arguing that the standpoint of the impartial spectator is constructed from within a given society, Smith's account, when used for determining principles of justice, retains Rawls's insistence that the people primarily concerned with the social contract should determine the political principles that will govern their society. Indeed, Smith's conception of impartiality is not very different from Rawls's conception: while Rawls writes that "the veil of ignorance prevents us from shaping our moral view to accord with our own particular attachments and interests" and that "we do not look at the social order from our situation but take up a point of view that everyone can adopt on an equal footing" (TJ 453), Smith, as we saw, understands the impartial spectator as a standpoint from which we view our and others' interests from a neutral perspective and from which we see that we are one of the multitude. And as is the case with the "original position," the impartiality inherent to the impartial spectator should be understood as part of the hypothetical conditions under which the principles of justice are determined: the conditions guarantee the reliability of agents' verdicts in constituting these principles, and if actual agents are not under those conditions, their verdicts are not necessarily reliable. In doing so, the account offers principles of justice that can transcend the biases and prejudices of the society that utilizes the hypothetical conditions. $^{22}$

Now, as we saw, both the "utilitarian challenge" and the "wrong type of impartiality challenge" are associated with the idea that utilitarianism - including, according to Rawls, impartial spectator theory - does not respect the distinction between persons, and mistakes impersonality for impartiality. However, recall that Smith's account shows a sensitivity toward respecting the dignity of other human beings - their status as persons who may not be treated in certain ways - which entails respect for the distinction between persons. The importance of the distinction between persons is also apparent in Smith's claim that "our regard for the multitude is compounded and made up of the particular regards which we feel for the different individuals of which it is composed" (TMS II.ii.3.10). Indeed, there is also a case to be made that Smith, who views the rules of justice not only as protecting individuals against injury but also as "inviolable" and "sacred" (TMS III.4.12 \& III.6.10), believed that individuals' interests are inviolable and sacred: in the same way that "in the ancient heathen religion, that holy ground which had been consecrated to some god, was not to be trod upon," so "the happiness of every innocent man is [. . .] rendered holy, consecrated, and hedged round against the approach of every other man; not to be wantonly trod upon, not even to be, in any respect, ignorantly and involuntarily violated, without requiring some

\footnotetext{
${ }^{22}$ Smith notes that the standpoint of the impartial spectator can be used to correct the reactions of the actual people we encounter if these reactions are not deemed appropriate from this standpoint (TMS III.2.32 \& VII.iii.3.9). Amartya Sen has argued that while Rawls's procedure "is not designed to address the limitations of partiality toward the shared prejudices or biases of the focal group," Smith's account does better, since it can bring in "distant perspectives that are detached [. . . from any parochialism of local beliefs that may be generally shared by all members of a given polity." Amartya Sen, Open and Closed Impartiality, The Journal of Philosophy, 99 (2002): 445-69, at p. 447 and Amartya Sen, What Do We Want from a Theory of Justice? The Journal of Philosophy, 103 (2006): 215-38, at p. 232. As I discuss in section 6, Sen is misinterpreting Smith, and, anyway, it is not clear why Rawls's hypothetical procedure cannot overcome the shared prejudices and biases of the focal group.
} 
expiation, some atonement in proportion to the greatness of such undesigned violation" (TMS II.iii.3.4). ${ }^{23}$ These claims are not entirely different from Rawls's claim that "each person possesses an inviolability founded on justice that even the welfare of society as a whole cannot override" (TJ 3). In terms of the impartial spectator account itself, while Smith conceptualized this spectator as a person "who has no particular relation either to ourselves, or to those whose interests are affected by our conduct, [. . . but is merely a man in general," 24 this does not make the theory guilty of mistaking impersonality for impartiality: the impartial spectator does not organize "the desires of all persons into one coherent system of desire," as Rawls put it, and does not fuse different persons into one person. Rather, the standpoint of the impartial spectator is one from which "we [. . .] see what relates to ourselves in its proper shape and dimensions" (TMS III.3.1; emphasis added), thus allowing us to bracket our own perspectives and, as discussed, see the situation from others' perspectives; that is, it allows us to understand our interests in the context of our own perspectives and compare them to the interests of others in the context of their perspectives, thus respecting the unique perspectives of individuals (which also strengthens the claim that the impartial spectator framework is not a mere utility-maximizing device) ${ }^{25}$

In response to the "insufficient content challenge," according to which the impartial spectator framework makes no assumptions from which the principles of justice may be derived, I grant that I have not demonstrated that specific principles of justice will be deduced from the impartial spectator framework. My primary aim was to show that the impartial spectator account is amenable to a version of the Rawlsian project. Nevertheless, I wish to make two general observations followed by a more concrete proposal. First, one could argue that Rawls and Smith are "partners in crime," since principles of justice cannot be deduced in either account. Recall that in Political Liberalism, Rawls conceded that his own conception of justice might not be the only one which satisfies the definition of a liberal political conception of justice. And in Justice as Fairness, Rawls admits that the ideal of deductive reasoning cannot be fully attained since, among other things, "there are indefinitely many considerations that may be appealed to in the original position and each alternative conception of justice is favored by some considerations and disfavored by others" (JF 133). Indeed, several commentators have argued that choice in the Rawlsian original position is indeterminate, ${ }^{26}$ or that the parties in the original position would not choose Rawls's two principles of justice. ${ }^{27}$ Moreover, Rawls criticized the impartial spectator framework before he came to realize

\footnotetext{
${ }^{23}$ This last observation is made in Griswold, Adam Smith and the Virtues of Enlightenment, pp. 237-38 and Darwall, Sympathetic Liberalism, p. 156.

${ }^{24}$ This quote is taken from a passage that first appeared in the 2nd edition of TMS, remained with minor variations in editions $3-5$, and was replaced by a slightly different passage in the 6 th edition (in particular, TMS III.2.31-32). The quoted passage can be found in a footnote on pp. 129-30 of the Glasgow Edition (1976) of TMS.

${ }^{25}$ The fact that Rawls thought otherwise may be the result of his focus on Hume's, rather than Smith's, model of sympathy and approbation when advancing the "utilitarian challenge" (TJ 162-63).

${ }^{26}$ Amartya Sen, The Idea of Justice (Cambridge, MA: Harvard University Press, 2009), pp. 11-12 and 56-58. The thought is often that the parties are deprived of so much information about themselves that they are psychologically incapable of making a (rational) choice. Samuel Freeman, Original Position (2019), Stanford Encyclopedia of Philosophy, ed. by Edward N. Zalta, <https://plato.stanford.edu/entries/original-position/>, sec. 3.

${ }^{27}$ For example, John Harsanyi has argued that the parties in the original position would choose the principle of average utility instead of the principles of justice. John Harsanyi, Can the Maximin Principle Serve
} 
the indeterminacy inherent in his own theory and so might have been more accepting of this framework had he reexamined it in his later writings. Second, I have provided reasons for favoring certain principles of justice, and I could do so because the impartial spectator framework does include relevant psychological and normative assumptions, such as the development of the impartial spectator within a given society, as well as the role of commutative justice, sympathy and imagination, and the desire to be worthy of approval. These assumptions are not part of Roderick Firth's ideal observer framework, on which Rawls relies when discussing the "insufficient content challenge" (TJ 162). Firth argued that " $\mathrm{X}$ is $\mathrm{P}$ [an ethical predicate]" means "any ideal observer would react to $\mathrm{x}$ in such and such a way under such and such conditions," where these conditions include, among other things, omnipercipience and omniscience with respect to the non-ethical facts. ${ }^{28}$ This account over-idealizes the observer in question and detaches him from our human sensibilities. It thus becomes unclear what epistemic access we have to the reactions of such an observer, or why his decisions should bind us.

One might argue that whatever one makes of the possibility of deducing particular principles from the hypothetical conditions in question, Rawls's theory is more determinate than the Smithian framework that I have proposed, since Rawls shows, at the very least, how the original position is a heuristic device for solving conflicts among (reasonable) conceptions of the good. As I noted at the outset, I will not be fully fleshing out the Smithian framework in this article, which will, no doubt, require additional psychological and normative assumptions. Nevertheless, I do wish to say a bit more about the proposed framework. I am in effect advancing a version of Rawls's suggestions according to which it is possible to (a) "supplement the impartial spectator definition with the contract point of view," (b) adopt "the sympathetic spectator idea" without characterizing "this spectator as conflating all desires into one system," and (c) implement the idea that agents are "to be guided by the principles someone would choose if he knew that he is to split, so to speak, into the many members of society" (TJ 162 \& 166). Rawls understands the last claim as a claim about the benevolent person, who loves the "plurality of persons as he loves himself," but Rawls argues that "nothing would have been gained by attributing benevolence to the parties in the original position." This is so because, "if the claims of these goods [of beloved individuals] clash, benevolence is at a loss as to how to proceed, as long anyway as it treats these individuals as separate persons. These higher-order sentiments do not include principles of right to adjudicate these conflicts" (TJ 166-67). In the account that I am proposing, a contract will indeed be needed between people adopting the standpoint of the impartial spectator; hence, my language of "agreement among those agents who adopt the standpoint of the impartial spectator" in section 2. I am also suggesting that, instead of conflating all desires into one system, litigants to the social contract should attempt to split into the many members of society and imagine being in these people's situations. Of course, as Rawls points out, benevolence - or, in the Smithian account, sympathy - cannot do all of the work by itself. Rather, the Smithian account makes use of our sympathetic reactions under suitable conditions, conditions of full knowledge and impartiality. It is these conditions that are supposed to serve as the basis for developing the principles of right that are needed in order to adjudicate conflicts. As

as the Basis for Morality? A Critique of John Rawls's Theory, American Political Science Review, 69 (1975): 594-606.

${ }^{28}$ Roderick Firth, Ethical Absolutism and the Ideal Observer, Philosophy and Phenomenological Research, 12 (1952): 317-45. 
I have argued, under these conditions, it is quite likely that principles similar to Rawls's two principles of justice will be developed and that utilitarian principles will be ruled out. This is already a substantial achievement, which gives some determinacy to the proposed framework. Therefore, while the Smithian approach requires further development, it is not as indeterminate as the Rawls of TJ thought: we have as much prima facie reason to be optimistic about the Smithian approach as we do about a Rawlsian one. ${ }^{29}$

\section{The case for political liberalism}

One of the aims of this article is to show that, insofar as the impartial spectator can provide us with principles of justice, Smith's account is one of political, rather than comprehensive, liberalism. Of course, if Rawls is in fact wrong in understanding the impartial spectator account in utilitarian terms, then what I called the "wrong type of liberalism challenge" does not arise for Smith's account, at least not in terms of utilitarianism serving as the framework of values that justifies political principles. Nevertheless, one could argue that Smith's impartial spectator might embody other frameworks of value, for example, Stoic, Aristotelian, or proto-Kantian values. However, whatever Smith's own commitments to various frameworks of value, there is nothing in the impartial spectator framework, as presented above, that suggests an appeal to specific overall ends and values. In particular, the idea of adopting a neutral standpoint, from which competing interests and perspectives are given equal standing and weighed against each other, would seem to be an idea that does "not presuppose any particular fully (or partially) comprehensive doctrine" and can be "shared by citizens regarded as free and equal," which is how Rawls understood political liberalism and its inclusion of ideas of the good that belong to "a reasonable political conception of justice" (PL 176). Moreover, the ambitions of political liberalism are such that political principles are justified by appeals to ideas that are already implicit in democratic society rather than by a comprehensive doctrine of the good. Since the impartial spectator grows out of our antecedent interactions with others and makes use of conceptions of (primarily commutative) justice that are already embedded in those interactions, the account can easily accommodate these ambitions: if the impartial spectator is constructed from within a society that is already relatively liberal and democratic, it will presumably provide principles of justice based (at least in part) on ideas that are already implicit in that very society.

Nevertheless, one could still object that Smith's impartial spectator account does presuppose a comprehensive doctrine of the good in the form of moral egalitarianism. The development of principles of justice based on moral egalitarianism may be objectionable for at least the following reasons: (a) when determining political principles, it is no less reasonable to give greater weight to the interests and perspectives of the people in the society that will be governed by those principles than to the interests and perspectives of people in other societies; (b) consideration of the perspectives of people in illiberal societies as equal to the perspectives of those in liberal societies, when attempting to determine political principles for the latter, risks undermining the liberal project. ${ }^{30}$ Now, when considering these objections in relation to Smith's account, it is important

\footnotetext{
${ }^{29} \mathrm{I}$ am grateful to an anonymous referee for pressing me to clarify these points.

${ }^{30}$ There is a case to be made that the scope of distributive justice should be wider than the citizens of a given state. However, Rawls, for his part, focused primarily on the duties of distributive justice that a given state owes its citizens. My aim in the current article is to stay within this Rawlsian framework.
} 
to distinguish two questions: (a) does Smith make claims which suggest that he endorsed moral egalitarianism independently of his impartial spectator account? (b) does the impartial spectator account presuppose or entail moral egalitarianism? Regarding (a), it might very well be the case that Smith advances a doctrine of basic equality of human beings as a normative principle and that he is thus a moral egalitarian, as some commentators have suggested. ${ }^{31}$ While the argument for this claim is not conclusive, ${ }^{32}$ what is important for the purposes of assessing the type of liberalism in question is not, as noted, Smith's commitment to various frameworks of value, but the impartial spectator account itself and the values inherent in that account which might bear on developing political principles. Indeed, whatever Rawls's more general views about moral egalitarianism are, he made it clear that, for political purposes, he is interested in the "moral agent" as "the free and equal citizen as a member of society, not the moral agent in general" (PL 109). Therefore, the crucial question is whether or not the impartial spectator account forces us to take into account the moral agent in general, as it were, or whether we can use this account to include only free and equal citizens as members of a given society.

Fleischacker and Darwall argue that the idea that we can and should identify with the perspective of every other person implicitly presupposes a commitment to the equal worth of those perspectives. ${ }^{33}$ Amartya Sen argues that in Smith's use of the impartial spectator, "the demands of impartiality require the invoking of disinterested judgments of 'any fair and impartial spectator', not necessarily (indeed sometimes ideally not) belonging to the focal group," noting that we should consider outsiders' perspectives and interests, so that we can prevent unfairness to those who are not a party to the social contract for that society. ${ }^{34}$ But is Smith's impartial spectator account one in which we are required to identify with the perspective of every other person and necessitated to take their interests into consideration? Sen, for example, misrepresents Smith in the crucial quote, since what Smith actually writes is that "we endeavour to examine our own conduct as we imagine any other fair and impartial spectator would examine it" (TMS III.1.2). In other words, Smith is making a point about the nature of the standpoint from which we should assess our own conduct, not a point about the set of actual or hypothetical people whose point of view we should take into account. More generally, the standpoint of the impartial spectator shows us that people's interests and perspectives should be given equal weight when considered from a neutral point of view. This is a claim about the equal worth of interests and perspectives of the set of people who are considered from the standpoint of the impartial spectator for a given purpose, a set whose size may vary as a function of the purpose. It is not a claim about the equal worth of all interests and perspectives, regardless of whether or not they are in the purview of the impartial spectator or of the purpose for which the standpoint of the impartial spectator is being utilized. Even Smith's talk of the person who adopts this

\footnotetext{
${ }^{31}$ See, for example, Darwall, Sympathetic Liberalism; Darwall, Equal Dignity in Adam Smith; Griswold, Adam Smith and the Virtues of Enlightenment, p. 12; Samuel Fleischacker, On Adam Smith's Wealth of Nations: A Philosophical Companion (Princeton, NJ: Princeton University Press, 2004), p. 74; Samuel Fleischacker, Adam Smith on Equality, in The Oxford Handbook of Adam Smith, ed. by Christopher J. Berry, Maria Pia Paganelli, and Craig Smith (Oxford: Oxford University Press, 2016), pp. 485-500.

${ }^{32}$ See, for example, Remy Debes, Adam Smith on Dignity and Equality, British Journal for the History of Philosophy, 20 (2012): 109-40.

${ }^{33}$ Fleischacker, Adam Smith on Equality, p. 487 and Darwall, Equal Dignity in Adam Smith, p. 132.

${ }^{34}$ Sen, Open and Closed Impartiality, p. 446 and Amartya Sen, The Contemporary Relevance of Adam Smith, in The Oxford Handbook of Adam Smith, ed. by Christopher J. Berry, Maria Pia Paganelli, and Craig Smith (Oxford: Oxford University Press, 2016), pp. 581-92, at pp. 589-90.
} 
standpoint as seeing that she is "but one of the multitude in no respect better than any other in it" does not specify who is to be included in this multitude, which can cover various sets of persons. Indeed, in one of the instances in which he makes his "one of the multitude" claim, in the context of a discussion of our special attachments to our country, Smith writes:

The patriot who lays down his life for the safety, or even for the vainglory of this society, appears to act with the most exact propriety. He appears to view himself in the light in which the impartial spectator naturally and necessarily views him, as but one of the multitude, in the eye of that equitable judge, of no more consequence than any other in it, but bound at all times to sacrifice and devote himself to the safety, to the service, and even to the glory, of the greater number. (TMS VI.ii.2.2)

Thus, the "multitude" in question can refer, for example, to the citizens of a certain state. So, while Smith's account allows for the possibility of taking the perspective and interests of every other person into consideration, it does not necessitate their inclusion in the name of egalitarianism.

\section{Conclusion}

In his A Theory of Justice, John Rawls failed to appreciate the nature of Adam Smith's impartial spectator account. By way of correcting Rawls's misconceptions, I have argued that the impartial spectator account, in conjunction with some of Smith's other views, offers the basis for a novel and alternative framework for developing principles of justice, and does so in the context of a political form of liberalism. Two points are worth emphasizing in conclusion. First, the current article is, of course, programmatic in nature. I have not offered a deduction of the principles of justice from the standpoint of the impartial spectator. One of my aims was to demonstrate that the impartial spectator account is amenable to a version of the Rawlsian project, including the absence of a comprehensive doctrine of the good that grounds the account. I hope that in doing so, the reader will agree that the proposed Smithian account for establishing just political principles, which appeals to the decisions of other-regarding, sympathetic individuals under conditions of full knowledge and impartiality, is an interesting sentimentalist alternative to the Rawlsian account. Second, I have not attempted to formulate "the natural rules of justice, independent of all positive institution," which, as Smith puts it, would establish "a system of what might properly be called natural jurisprudence, or a theory of the general principles which ought to run through, and be the foundation of, the laws of all nations" (TMS VII.iv.37). Smith never finished writing the part of the system that he called "natural jurisprudence," and, as some commentators note, it is far from clear that such a project - understood as providing a set of laws that hold across all societies in all eras - is feasible, given many of Smith's other commitments (especially the context-sensitivity of the impartial spectator). ${ }^{35}$ My aim in this article was to show that Smith's account can provide principles of justice for societies that are already relatively liberal and democratic, in the same spirit as Rawls's project. As noted, the ambitions of political liberalism are such that political principles are justified by appeal to

\footnotetext{
${ }^{35}$ Fleischacker, On Adam Smith's Wealth of Nations: A Philosophical Companion, p. 168 and Griswold, Adam Smith and the Virtues of Enlightenment, pp. 256-57.
} 
ideas that are already implicit in democratic society rather than by a comprehensive doctrine of the good. Therefore, while it may be the case that the impartial spectator framework cannot yield universal principles that are the same for all societies, it can yield just principles for societies that are already fairly liberal and democratic and that are interested in formulating principles of justice. ${ }^{36}$

\footnotetext{
${ }^{36}$ I owe my deepest gratitude to Martha Nussbaum for initially encouraging me to pursue this project, as well as to Jochen Bojanowski, Samuel Fleischacker, Ben Miller, and David Sussman for their invaluable feedback and encouragement. I would also like to thank audiences at the following venues for their feedback: PPE Society Meeting (2020), Liberty Fund (2019), International Adam Smith Society Conference (2019), and Mediterranean Society for Enlightenment Studies Conference (2016). Finally, I would like to thank two anonymous referees for Utilitas, whose excellent comments greatly helped in improving the article.
}

Cite this article: Ben-Moshe N (2021). Comprehensive or Political Liberalism? The Impartial Spectator and the Justification of Political Principles. Utilitas 33, 253-269. https://doi.org/10.1017/S0953820820000394 